\title{
HUBUNGAN KOMUNIKASI TERAPEUTIK PERAWAT DENGAN KEPUASAN PASIEN RAWAT INAP DI PUSKESMAS WOTU KABUPATEN LUWU TIMUR
}

\section{THE RELATIONSHIP BETWEEN NURSES THERAPEUTIC COMMUNICATION WITH INPATIENT SATISFACTION AT THE WOTU HEALTH CENTER IN EAST LUWU REGENCY}

\author{
Helmy Kahar Achmad', Wahidin' ${ }^{\text {, }}$ Halim $^{3}$ \\ ${ }^{1}$ Puskesmas Wotu Kabupaten Luwu Timur. \\ e-mail : helmykahardokter@gmail.com \\ ${ }^{2}$ Sekolah Tinggi Ilmu Administrasi-Lembaga Administrasi Negara Makassar \\ e-mail : wahidin_mussi@yahoo.co.id \\ ${ }^{3}$ Sekolah Tinggi Ilmu Administrasi-Lembaga Administrasi Negara Makassar \\ e-mail: halim.recht@gmail.com
}

\begin{abstract}
Abstrak
Salah satu faktor yang mempengaruhi kepuasan pasien terhadap pelayanan kesehatan adalah komunikasi yang dilakukan oleh tenaga kesehatan. Tujuan penelitian ini adalah untuk menganalisis hubungan komunikasi terapeutik perawat dari aspek keterbukaan, empati, sifat mendukung perawat, sikap positif perawat dan kesetaraan antara perawat dan pasien dengan kepuasan pasien rawat inap di Puskesmas Wotu Kabupaten Luwu Timur. Jenis penelitian ini adalah penelitian observasional analitik, dengan desain cross sectional study. Populasi dan sampel dalam penelitian ini sebanyak 87 responden (sampel jenuh) dengan teknik penarikan sampel Purposive Sampling. Hasil penelitian ini menunjukkan bahwa terdapat hubungan antara komunikasi terapeutik ditinjau dari aspek keterbukaan, empati, sifat mendukung perawat, sikap positif perawat dan kesetaraan antara perawat dan pasien dengan kepuasan pasien rawat inap di Puskesmas Wotu. Puskesmas Wotu dapat meningkatkan kepuasan pasien dengan menambah keterampilan para perawat di instalasi rawat inap Puskesmas Wotu.
\end{abstract}

Kata kunci: Komunikasi Terapeutik, Kepuasan Pasien.

\begin{abstract}
One of the factors that affects patient satisfaction in health care is the communication done by healthcare personnel. The purpose of this research is to analyse the therapeutic communication relationship of nurses from the aspect of openness, empathy, nursing support, positive attitudes of nurses and equality between nurses and patients with the satisfaction of inpatient patients in Wotu Puskesmas Luwu Timur district. the type of research is analytical observational research, with cross sectional study design. The population and samples in this study were 87 respondents (saturated samples) with Purposive Sampling technique. The results of this study showed that the therapeutic communication of nurses from the aspect of openness, empathy, nursing support, positive attitudes of nurses and equality between nurses and patients are linked closely to the patient satisfaction in Wotu Puskesmas. The Wotu Puskesmas can increase patient satisfaction by increasing the skills of nurses in the Wotu Puskesmas inpatient installation.
\end{abstract}

Keywords: Therapeutic Communication, Patient Satisfaction 


\section{PENDAHULUAN}

Puskesmas merupakan organisasi kesehatan fungsional yang merupakan pusat pengembangan kesehatan masyarakat yang juga membina peran serta masyarakat dan memberikan pelayanan secara menyeluruh dan terpadu kepada masyarakat di wilayah kerjanya dalam bentuk kegiatan pokok (Ayuningtyas, 2015).

Puskesmas Wotu yang menjadi lokus penelitian mempunyai fungsi penyelenggaraan pelayanan kesehatan salah satunya yaitu pelayanan keperawatan di instalasi rawat inap.

Jika dilihat pada table 1 tentang persentasi keluhan pasien di Puskesmas Wotu pada tahun 2018 maka instalasi rawat inap memiliki persentasi keluhan tertinggi yakni $40 \%$ dari seluruh keluhan yang masuk pada puskesmas tersebut.

Tabel 1

Persentase Keluhan Pasien di Puskesmas Wotu Tahun 2018

\begin{tabular}{lc}
\hline \multicolumn{1}{c}{ Uraian } & Persentase \\
\hline Poliklinik umum rawat Jalan & $25 \%$ \\
\hline Instalasi Rawat Inap & $40 \%$ \\
\hline Pelayanan bagian Pendaftaran & $5 \%$ \\
\hline Pelayanan Administrasi & $10 \%$ \\
\hline Pelayanan Perawat dan Pegawai Puskesmas & $15 \%$ \\
\hline Fasilitas & $5 \%$ \\
\hline
\end{tabular}

Sumber: Tata Usaha PKM Wotu Tahun 2019

Sebagai puskesmas yang telah terakreditasi, seharusnya manajemen puskesmas memberikan pelayanan yang memuaskan kepada pasien baik dalam bentuk fasilitas maupun komunikasi antara dokter dan pasien. Jika hal ini tidak dimiliki, maka akan membuat pasien merasa tidak nyaman karena yang mereka harapkan adalah sakit ataupun keluhan mereka dapat berkurang dan hilang.

Penyelenggaraan pelayanan keperawatan di puskesmas ditentukan oleh tiga komponen utama antara lain, jenis pelayanan yang diberikan, manajemen sebagai pengelola dan tenaga keperawatan sebagai pemberi pelayanan keperawatan. Ketiga komponen tersebut untuk memberikan kepuasan kepada pasien atau pelanggan puskesmas.

Kepuasan pelanggan adalah hasil yang dirasakan oleh pelanggan setelah menerima pelayanan dari sebuah perusahaan (Barkelay \& Saylor, 2010). Pelayanan keperawatan yang berkualitas tidak hanya ditentukan oleh ketepatan dalam memberikan pelayanan tetapi dengan membina hubungan komunikasi yang baik yang sifatnya terapi (Nursalam, 2014).

Komunikasi berperan penting dalam menjalankan proses administrasi dan interaksi antar elemen pada suatu kelompok atau organisasi. Orang-orang yang berhubungan dengan komunikasi yang baik akan sangat membantu semua proses yang ada dalam suatu organisasi tersebut. Tanpa adanya komunikasi yang baik dan benar besar kemungkinan semua proses di dalam organisasi tersebut tidak akan berjalan 
dengan maksimal dan sesuai dengan yang telah direncanakan. Komunikasi mengikat kesatuan organisasi dan membantu anggota-anggota organisasi mencapai tujuan individu dan juga organisasi. Jika sebuah organisasi sampai pada titik di mana komunikasi dalam organisasi tidak seefektif yang seharusnya, maka organisasi itu tidak akan berfungsi seefektif yang seharusnya.

Dalam menghadapi pasien yang multikultural dan memiliki latar belakang yang berbeda beda, seorang perawat sangat membutuhkan keterampilan khusus dalam berkomunikasi. Perawat sebagai ujung tombak pelayanan terhadap pasien dan keluarganya di puskesmas. Perawat adalah sumber daya yang paling banyak menyumbang sebagai pendukung kepuasan kepada pasien. Perawat memberikan pengaruh besar untuk menentukan kualitas pelayanan terhadap pasien di puskesmas, karena frekuensi pertemuannya dengan pasien yang paling sering dalam memberikan pelayanan kepada pasien. Hal ini dilakukan melalui interaksi antara perawat dan pasien, perawat dan profesional kesehatan lain, serta perawat dan komunitas (Andriani \& Putra, 2014).

Komunikasi merupakan kunci kesuksesan pelayanan kesehatan di puskesmas. Dalam setiap tindakan keperawatan, perawat melakukan komunikasi yang sifatnya terapi. Kelemahan dalam berkomunikasi merupakan masalah serius baik bagi perawat maupun bagi klien.

Menurut Ginting (2017) Komunikasi berasal dari bahasa latin communicare yang berarti to share (berbagi) dan merupakan sebuah aktivitas penyampaian informasi melalui pertukaran pikiran, pesan atau informasi dengan ucapan, visual, sinyal, tulisan, atau perilaku. Ini adalah pertukaran informasi yang bermakna di antara dua atau lebih mahluk hidup.

Dalam dunia kesehatan, kegiatan berkomunikasi juga dilakukan oleh perawat terhadap pasien. Komunikasi terapeutik adalah proses penyampaian pesan, makna dan pemahaman perawat untuk memfasilitasi proses penyembuhan pasien. (Murwani \& Istichomah, 2009)

Hal ini senada dengan pengertian komunikasi terapeutik yang dikemukakan oleh Siti, dkk (2016), yakni komunikasi profesional yang mengarah pada tujuan penyembuhan pasien. Sementara itu, dalam uraian Ketnawati dan Ruhyana (2017) mengatakan bahwa komunikasi terapeutik adalah komunikasi yang direncanakan, disengaja, dan merupakan tindakan profesional. Komunikasi terapeutik menurut beberapa ahli merupakan komunikasi yang direncanakan secara sadar, bertujuan, kegiatannya difokuskan 
pada kesembuhan pasien, perawat yang memiliki keterampilan berkomunikasi tidak saja akan mudah menjalin hubungan rasa percaya dengan pasien, juga mencegah terjadinya masalah illegal, memberikan kepuasan profesional dalam pelayanan keperawatan dan meningkatkan citra profesi keperawatan serta citra puskesmas.

Beberapa tujuan komunikasi terapeutik seperti yang dijelaskan oleh Anjaswarni (2016) yaitu membantu mengatasi masalah klien untuk mengurangi beban perasaan dan pikiran, membantu mengambil tindakan yang efektif untuk klien/pasien, memperbaiki pengalaman emosional klien dan mencapai tingkat kesembuhan yang diharapkan.

Komunikasi terapeutik tidak sama dengan komunikasi sosial. Komunikasi sosial tidak memiliki tujuan tertentu dan biasanya pelaksanaan komunikasi ini terjadi begitu saja. Sebaliknya komunikasi terapeutik mempunyai tujuan dan fungsi untuk membantu klien memecahkan masalah, atau mendorong klien untuk melakukan tindakan yang baik bagi penyembuhan serta peningkatan kesehatannya. Untuk itu, pelaksanaan komunikasi terapeutik harus direncanakan serta terstruktur dengan baik. Menurut Anjaswarni (2016) bahwa struktur dalam proses komunikasi terapeutik terdiri atas empat tahap, yaitu tahap persiapan atau prainteraksi, tahap perkenalan atau orientasi, tahap kerja, dan tahap terminasi.

Komunikasi interpersonal di dalam dunia kesehatan dikenal sebagai Komunikasi Terapeutik. Di mana dokter dan paramedis lainnya harus mengetahui keadaan dan tanggapan pasien saat diperiksa, demikian juga pasien mengetahui perhatian yang diberikan oleh dokter dan tenaga paramedik. (Siregar, 2016)

Pasien tidak hanya mengalami penderitaan secara fisik namun juga meliputi jiwa atau mental, seperti mengalami gangguan emosi yakni mudah tersinggung, patah semangat disebabkan penyakit yang dideritanya. Sering timbul perasaan sedih, takut, dan cemas dalam diri pasien jika penyakit yang diderita cukup berat bahkan bila divonis sulit untuk disembuhkan. Di sinilah peran komunikasi terapeutik yang dilakukan dokter dan paramedis terhadap pasien sangat penting sebagai salah satu bentuk pelayanan kesehatan di rumah sakit.

Kepuasan pasien merupakan salah satu indikator kualitas pelayanan yang diberikan dan kepuasan pasien adalah suatu modal untuk mendapatkan pasien lebih banyak dan untuk mendapatkan pasien yang loyal (setia). Pasien loyal akan menggunakan kembali pelayanan kesehatan yang sama bila mereka 
membutuhkan kembali. Bahkan pasien yang loyal akan mengajak orang lain untuk menggunakan pelayanan kesehatan yang sama. Pasien loyal adalah "sarana promosi" yang murah. (Supriyanto \& Ernawati, 2010)

Menurut Waison, Walter dan White dalam Agus dan Dyah (2008) salah satu faktor yang mempengaruhi kepuasan pasien terhadap pelayanan puskesmas adalah kepuasan terhadap komunikasi yang dilakukan oleh tenaga kesehatan khususnya perawat. Hal ini dijelaskan oleh beberapa ahli bahwa masalah komunikasi terapeutik perawat yang masih sering terjadi adalah masih banyak petugas yang terlalu sibuk dengan tugas kesehariannya sehingga tidak ada waktu untuk berkomunikasi terapeutik dengan pasiennya, bahkan masih ada perawat yang terkesan judes, tidak ramah, serta tidak memberikan informasi yang dibutuhkan oleh pasien dan keluarga. Hal tersebut menyebabkan klien dan keluarga sebagai pengguna pelayanan kesehatan tidak merasa puas terhadap pelayanan yang diberikan. Sedangkan untuk mengukur tingkat kepuasan pasien digunakan indikator yang dikemukakan oleh Tjiptono dan Diana (2015).

Beberapa penelitian sebelumnya seperti yang dilakukan oleh Walansendow, dkk (2017) tentang hubungan antara sikap dan teknik komunikasi terapeutik perawat dengan kepuasan pasien RSU GMIM Kalooran Amurang menunjukkan perawat yang menerapkan komunikasi terapeutik dengan dimensi sikap yang baik $(80,0 \%)$, didapatkan pasien yang menyatakan puas sebanyak (78,2\%). Penelitian yang dilakukan oleh Walansendow, dkk (2017), menunjukkan perawat yang menerapkan komunikasi terapeutik dengan dimensi sikap hormat perawat yang cukup mempengaruhi tingkat kepuasan pasien sebanyak $(88,1 \%)$, Empati perawat yang cukup maka mempengaruhi tingkat kepuasan pasien sebanyak $(67,3 \%)$, dan penelitian yang dilakukan oleh Negi, dkk (2017) tentang kualitas komunikasi terapeutik perawat dan kepuasan pasien di Rumah Sakit Uttarakh dan India, menunjukkan (90\%) pasien merasa puas mengenai informasi perawat tentang status dan perawatan kesehatan mereka, hanya $(4,5 \%)$ pasien yang mengatakan mereka cepat di tangani serta hanya $37,3 \%$ pasien menyatakan bahwa perawat bersikap sopan dan rendah hati.

Penelitian Walansendow, dkk (2017) melihat dari sudut pandang administrasi dan tidak seperti peneliti komunikasi terapeutik lain karena seorang perawat dituntut memiliki kompetensi dan keterampilan berkomunikasi secara terapeutik dalam menjalankan perannya sehingga dapat menentukan keberhasilan 
pelayanan atau asuhan keperawatan yang profesional.

Untuk terwujudnya komunikasi terapeutik yang efektif, maka komunikasi harus memenuhi prinsip-prinsip humanistik yaitu adanya keterbukaan (openess), empati (emphaty), sifat mendukung (supportiveness), sikap positif (positiveness) dan kesetaraan (equality) antara perawat dan pasien. (Siregar, 2016). Sejalan dengan hasil penelitian Asdawati, S., A, I., Kapalawi, \& Irwandy. (2014). bahwa tingkat kepuasan pasien dalam pelaksanaan komunikasi efektif dokter di Instalasi Rawat Jalan RSUD Kota Makassar berada pada kategori puas dengan persentase sebesar $93,5 \%$ dan yang tidak puas hanya sebesar $6,5 \%$ dengan uraian tingkat kepuasan pasien berdasarkan setiap dimensinya dimensi keterbukaan, puas $(73 \%)$ Dimensi sikap positif, puas (79,5\%) Dimensi sifat mendukung, puas (76\%) dan tidak puas (24\%). Dimensi empati, puas $(68,5 \%)$ dan tidak puas (31,5\%). Dimensi kesetaraan, puas $(71,5 \%)$ dan tidak puas $(28,5 \%)$.

Sukses dokter dan paramedis dalam menangani keluhan-keluhan pasiennya tidak saja terletak pada hasil pendidikan dan kemahiran dalam bidang kedokteranyya melainkan oleh unsur-unsur pribadi dan dokter serta paramedis itu sendiri (seperti kecakapan empatik dan kemampuan berkomunikasi secara aktif terhadap para pasiennya) dan harapan atau pdanangan atau masyarakat yang dilayaninya.

Jadi kualitas pelayanan adalah suatu pelayanan yang diberikan kepada pasien oleh tenaga kesehatan secara profesional dengan empati, perhatian serta tanggap akan kebutuhan pasien untuk meningkatkan derajat kesehatan pasien sesuai dengan ilmu pengetahuan, keterampilan, dan stdanar yang berlaku. Penelitian ini ingin melihat hubungan komunikasi terapeutik perawat dengan dimensi keterbukaan perawat, empati perawat, sifat mendukung perawat, sikap positif perawat, dan kesetaraan antar perawat dan pasien dengan kepuasan pasien rawat inap di Puskesmas Wotu.

\section{METODE PENELITIAN}

Jenis penelitian ini adalah penelitian observasional analitik, dengan desain cross sectional study, yaitu suatu rancangan yang mengkaji dinamika korelasi/asosiasi antara variabel independen (Keterbukaan, empati, sifat mendukung, sikap positif, dan kesetaraan) dengan variabel dependent (kepuasan) pada saat bersamaan (point time approach) di instalasi rawat inap Puskesmas Wotu. Penelitian ini dilakukan di Puskesmas Wotu di Instalasi rawat inap 
tahun 2019 dengan Populasi sebanyak 87 pasien rawat inap.

Metode penarikan sampel dalam penelitian ini yakni sampel jenuh atau sampel yang ditarik dalam penelitian ini adalah seluruh anggota populasi.

Sumber data yang digunakan dalam penelitian ini yakni data primer atau data penelitian yang diperoleh secara langsung dari sumber asli (bukan perantara). Data primer diperoleh dari responden yang menjawab pertanyaan survey dengan menggunakan instrument berupa kuesioner. Jenis data pada data primer adalah data ordinal menggunakan skala Likert.

Data sekunder adalah data yang di peroleh dari instansi terkait sebagai pendukung dan pelengkap dari data primer yang ada relevansinya dengan penelitian. Sebelum kuesioner digunakan untuk pengambilan data, terlebih dahulu dilakukan uji coba, yaitu uji validitas dan reliabilitas. Setelah data terkumpul, dilanjutkan dengan tahap analisis data dengan menggunakan komputer dalam program SPSS for windows dengan 2 (dua) tahap; yang pertama melakukan analisis univariat terhadap variabel dependen dan indepanden sehingga didapatkan gambaran deskriptif setiap variabel dalam bentuk distribusi persentasi. Tahap kedua yakni melakukan analisis bivariate untuk melihat hubungan antara variabel independen dengan variabel dependen dengan uji chisquare dengan melihat $p$ value yang lebih kecil dari 0,05.

\section{HASIL PENELITIAN}

Hasil uji validitas menunjukkan bahwa semua pernyataan bias dianggap valid karena nilai Corrected Item Correlation semua pernyataan kesemuanya lebih dari 0,30, sedangkan hasil uji reliabilitas menunjukkan bahwa nilai koefisien reliabilitas lebih besar dari 0,60 sehingga instrument yang digunakan dinyatakan reliabel.

Objek dalam penelitian ini adalah pasien rawat inap di Puskesmas Wotu pada bulan Mei 2019 yang berjumlah 87 orang. Berikut ini adalah hasil penyajian mengenai karakteristik responden.

- jenis kelamin wanita memiliki persentase lebih tinggi dibandingkan dengan responden berjenis kelamin pria.

- responden didominasi oleh usia 30-40 tahun atau sebanyak 47\%. Hal ini menunjukkan bahwa mayoritas responden berada pada usia produktif.

- responden didominasi oleh pasien yang berpendidikan SMA/SMK/Sederajat atau sebanyak 55\%. Hal ini menunjukkan bahwa mayoritas responden telah menyelesaikan Pendidikan dasar Sembilan tahun 
sehingga dapat dikatakan bahwa penduduk dalam kategori berpendidikan.

- sebagian besar responden berprofesi sebagai petani yakni sebanyak $31 \%$ dan Ibu Rumah Tangga sebanyak 26\%. Ini menunjukkan bahwa responden memiliki pekerjaan yang membutuhkan aktifitas fisik yang lebih besar dibanding yang lain.

\section{Hubungan aspek Keterbukaan dengan}

\section{Kepuasan Pasien}

Hasil analisis data menunjukkan hubungan antara variabel independen berupa keterbukaan perawat dengan variabel dependen yaitu kepuasan pasien rawat inap. Berdasarkan variabel keterbukaan perawat, dari total 64 responden yang menyatakan keterbukaan perawat dalam kategori baik, terdapat 51 $(79,7 \%)$ responden yang merasa puas, 11 $(17,2 \%)$ responden cukup puas dan 2 $(3,1 \%)$ responden kurang puas dengan pelayanan di Puskesmas Wotu. Selanjutnya, dari total 17 responden yang menyatakan keterbukaan perawat dalam kategori cukup baik, terdapat $3(17,6 \%)$ responden yang merasa puas, $7(41,2 \%)$ responden cukup puas dan 7 (41,2\%) responden kurang puas dengan pelayanan di Puskesmas Wotu.
Sedangkan dari total 6 responden yang menyatakan keterbukaan perawat kurang baik, terdapat 1 responden $(16,7 \%)$ yang merasa cukup puas terhadap pelayanan kesehatan dan dan 5 responden $(83,3 \%)$ yang merasa kurang puas. Hasil uji statistik dengan menggunakan uji chisquare diperoleh nilai $p=0,000$, karena nilai $p$ value $<0,05$ maka ada hubungan aspek keterbukaan perawat terhadap kepuasan pasien rawat inap di Puskesmas Wotu.

\section{Hubungan aspek Empati dengan Kepuasan Pasien}

Hasil analisis data menunjukkan hubungan antara variabel independen berupa Empati perawat dengan variabel dependen yaitu kepuasan pasien rawat inap. Berdasarkan variabel Empati perawat, dari total 64 responden yang menyatakan Empati perawat dalam kategori baik, terdapat $50(78,1 \%)$ responden yang merasa puas, $9(14,1 \%)$ responden cukup puas dan $5(7,8 \%)$ responden kurang puas dengan pelayanan di Puskesmas Wotu. Selanjutnya, dari total 17 responden yang menyatakan Empati perawat dalam kategori cukup baik, terdapat $4(23,5 \%)$ responden yang merasa puas, $9(52,9 \%)$ responden cukup puas dan 4 (23,5\%) responden kurang puas dengan pelayanan di Puskesmas Wotu. 
Sedangkan dari total 6 responden yang menyatakan Empati perawat kurang baik, terdapat 1 responden (16,7\%) yang merasa cukup puas terhadap pelayanan kesehatan dan dan 5 responden $(83,3 \%)$ yang merasa kurang puas. Hasil uji statistik dengan menggunakan uji chi-square diperoleh nilai $p=0,000$, karena nilai $p$ value $<0,05$ maka ada hubungan aspek empati perawat terhadap kepuasan pasien rawat inap di Puskesmas Wotu.

\section{Hubungan aspek Sifap Mendukung} dengan Kepuasan Pasien

Hasil analisis data menunjukkan hubungan antara variabel independen berupa sifat mendukung perawat dengan variabel dependen yaitu kepuasan pasien rawat inap. Berdasarkan variabel sifat mendukung perawat, dari total 64 responden yang menyatakan sifat mendukung perawat dalam kategori baik, terdapat $51(79,7 \%)$ responden yang merasa puas, $11(17,2 \%)$ responden cukup puas dan $2(3,1 \%)$ responden kurang puas dengan pelayanan di Puskesmas Wotu. Selanjutnya, dari total 17 responden yang menyatakan sifat mendukung perawat dalam kategori cukup baik, terdapat 3 $(17,6 \%)$ responden yang merasa puas, 7 $(41,2 \%)$ responden cukup puas dan 7 $(41,2 \%)$ responden kurang puas dengan pelayanan di Puskesmas Wotu.
Sedangkan dari total 6 responden yang menyatakan sifat mendukung perawat kurang baik, terdapat 1 responden $(16,7 \%)$ yang merasa cukup puas terhadap pelayanan kesehatan dan dan 5 responden $(83,3 \%)$ yang merasa kurang puas. Hasil uji statistik dengan menggunakan uji chisquare diperoleh nilai $p=0,000$, karena nilai $p$ value $<0,05$ maka ada hubungan aspek sifat mendukung perawat terhadap kepuasan pasien rawat inap di Puskesmas Wotu

\section{Hubungan aspek Sifat mendukung dengan Kepuasan Pasien}

Hasil analisis data menunjukkan hubungan antara variabel independen berupa sikap positif perawat dengan variabel dependen yaitu kepuasan pasien rawat inap. Berdasarkan variabel sikap positif perawat, dari total 60 responden yang menyatakan sikap positif perawat dalam kategori baik, terdapat $46(76,7 \%)$ responden yang merasa puas, $10(16,7 \%)$ responden cukup puas dan $4(6,7 \%)$ responden kurang puas dengan pelayanan di Puskesmas Wotu. Selanjutnya, dari total 21 responden yang menyatakan sikap positif perawat dalam kategori cukup baik, terdapat $8(38,1 \%)$ responden yang merasa puas, $8(38,1 \%)$ responden cukup puas dan $5(23,8 \%)$ responden kurang puas dengan pelayanan di Puskesmas Wotu. 
Sedangkan dari total 6 responden yang menyatakan sikap positif perawat kurang baik, terdapat 1 responden $(16,7 \%)$ yang merasa cukup puas terhadap pelayanan kesehatan dan dan 5 responden $(83,3 \%)$ yang merasa kurang puas. Hasil uji statistik dengan menggunakan uji chisquare diperoleh nilai $p=0,000$, karena nilai $p$ value $<0,05$ maka ada hubungan aspek sikap positif perawat terhadap kepuasan pasien rawat inap di Puskesmas Wotu.

\section{Hubungan aspek Kesetaraan dengan}

\section{Kepuasan Pasien}

Hasil analisis data menunjukkan hubungan antara variabel independen berupa kesetaraan antara perawat dan pasien dengan variabel dependen yaitu kepuasan pasien rawat inap. Berdasarkan variabel kesetaraan antara perawat dan pasien, dari total 69 responden yang menyatakan kesetaraan antara perawat dan pasien dalam kategori baik, terdapat 51 $(73,9 \%)$ responden yang merasa puas, 11 $(15,9 \%)$ responden cukup puas dan 7 $(10,1 \%)$ responden kurang puas dengan pelayanan di Puskesmas Wotu. Selanjutnya, dari total 13 responden yang menyatakan kesetaraan antara perawat dan pasien dalam kategori cukup baik, terdapat $3(23,1 \%)$ responden yang merasa puas, 7 $(53,8 \%)$ responden cukup puas dan 3
$(23,1 \%)$ responden kurang puas dengan pelayanan di Puskesmas Wotu.

Sedangkan dari total 5 responden yang menyatakan kesetaraan antara perawat dan pasien kurang baik, terdapat 1 responden $(20 \%)$ yang merasa cukup puas terhadap pelayanan kesehatan dan dan 4 responden (80\%) yang merasa kurang puas. Hasil uji statistik dengan menggunakan uji chi-square diperoleh nilai $p=0,000$, karena nilai $p$ value $<0,05$ maka ada hubungan aspek kesetaraan antara perawat dan pasien terhadap kepuasan pasien rawat inap di Puskesmas Wotu.

\section{PEMBAHASAN}

Berdasarkan hasil penelitian dan pengolahan data dengan menggunakan uji statistik, maka setiap variabel akan dibahas dan diuraikan satu per satu sebagai berikut:

\section{Hubungan Aspek Keterbukaan Perawat terhadap Kepuasan Pasien Rawat Inap di Puskesmas Wotu}

Keterbukaan (openess) didefinisikan sebagai kemauan menanggapi dengan senang hati informasi yang diterima di dalam menghadapi hubungan antarpribadi. Kualitas keterbukaan mengacu pada tiga aspek dari komunikasi interpersonal.

Aspek Pertama, komunikator interpersonal yang efektif harus terbuka kepada komunikannya. Hal ini tidaklah 
berarti bahwa orang harus dengan segera membukakan semua riwayat hidupnya. Memang ini mungkin menarik, tetapi biasanya tidak membantu komunikasi. Sebaliknya, harus ada kesediaan untuk membuka diri mengungkapkan informasi yang biasanya disembunyikan, asalkan pengungkapan diri ini patut dan wajar. Aspek Kedua, mengacu pada kesediaan komunikator untuk bereaksi secara jujur terhadap stimulus yang datang. Orang yang diam, tidak kritis, dan tidak tanggap pada umumnya merupakan komunikan yang menjemukan. Bila ingin komunikan bereaksi terhadap apa yang komunikator ucapkan, komunikator dapat emperlihatkan keterbukaan dengan cara bereaksi secara spontan terhadap orang lain. Aspek Ketiga, menyangkut kepemilikan perasaan dan pikiran di mana komunikator mengakui bahwa perasaan dan pikiran yang diungkapkannya adalah miliknya dan ia bertanggungjawab atasnya.

Berdasarkan hasil penelitian diketahui bahwa mayoritas perilaku keterbukaan perawat dalam menangani pasien dalam kategori baik. Hal ini terlihat dari hasil jawaban kuasioner aspek keterbukaan perawat yang sebagian besar menjawab dengan baik. Akan tetapi, ada juga beberapa pasien yang memberikan penilaian yang kurang baik.
Perawat di Puskesmas wotu saling membuka diri (openess) dengan saling sapa antara perawat dan pasien. Perawat mampu mengajak pasien untuk berkomunikasi dengan mengawali dengan pertanyaan ringan berkaitan dengan diri pasien.

Aspek keterbukaan perawat merupakan tingkah laku perawat dalam memberikan asuhan keperawatan. Perawat melalui pertemuan dengan klien, dapat meningkatkan kemampuannya dengan belajar dari pengalaman ketika bertemu klien, sedangkan dengan mendengarkan keluhan pasien dapat membuat perawat secara langsung terlibat dalam kehidupan klien. Perawat akan merespon secara benar setelah bertemu dengan klien dan keluargannya. Ekspresi wajah pasien dapat membantu perawat menolong pasien mencari cara untuk mendapatkan kedamaian. Perawat telah memberikan pelayanan kesehatan yang baik terhadap pasien, tetapi perawat masih perlu memperhatikan kinerja mutu pelayanan kesehatan untuk meningkatkan kepercayaan pasien sehingga kunjungan ulang pasien bertambah.

Dari hasil uji statistik memperlihatkan bahwa ada pengaruh Keterbukaan Perawat terhadap kepuasan pasien rawat inap Puskesmas Wotu. Keterbukaan perawat sangat mempengaruhi kepuasan pasien, apabila 
pelayanan yang diberikan sudah sesuai dengan kebutuhan pasien dan diberikan dengan cara yang ramah, terbuka dan jujur apa adanya pada waktu mereka dirawat sesuai sumber daya yang dimiliki, maka pasien akan merasakan kepuasan yang tinggi.

Ditinjau dari aspek keterbukaan, penelitian ini sesuai dengan hasil penelitian Asdawati, S., A, I., Kapalawi, \& Irwandy. (2014) yang juga menemukan bahwa adanya hubungan aspek keterbukaan terhadap kepuasan pasien di Instalasi Rawat Jalan RSUD Kota Makassar. Selain itu, hasil penelitian ini juga menegaskan konsep yang dikembangkan oleh Siregar (2016).

\section{Hubungan Aspek Empati Perawat dengan Kepuasan Pasien Rawat Inap di Puskesmas Wotu}

Empati menurut Devito (1997) adalah kemampuan seseorang untuk mengetahui apa yang sedang dialami orang lain pada suatu saat tertentu, dari sudut pandang orang lain itu, melalui kacamata orang lain itu. Berbeda dengan simpati yang artinya adalah merasakan bagi orang lain. Orang yang berempati mampu memahami motivasi dan pengalaman orang lain, perasaan dan sikap mereka, serta harapan dan keinginan mereka untuk masa mendatang sehingga dapat mengkomunikasikan empati, baik secara verbal maupun nonverbal.

Orang-orang yang datang ke rumah sakit untuk berobat atau memerlukan perawatan medis adalah orang-orang yang berada dalam situasi psikologis yang cemas dan panik, apalagi bagi pasien rawat inap. Mereka diliputi rasa panik dan cemas. Panik karena harus berpisah dari anggota keluarga yang lain, panik karena menderita suatu penyakit, panik karena kemampuan keuangan, dan lain-lain. Dokter dan paramedis harus memahami situasi psikologis seperti itu, sehingga bila ada perilaku penolakan dari pasien, dokter dan paramedis atau perawat dapat memakluminya. Empati perawat dalam menangani pasien dalam kategori baik. Hal ini terlihat dari hasil jawaban kuasioner aspek empati perawat yang sebagian besar menjawab dengan baik. Perawat dapat merasakan apa yang sedang dirasakan dan keluhan-keluhan pasien selama perawatan.

Berdasarkan hasil analisis data dapat diketahui adanya pengaruh antara variabel independen berupa Empati perawat dengan variabel dependen yaitu kepuasan pasien rawat inap Puskesmas Wotu. Selain itu, dari data di atas menunjukkan bahwa mayoritas responden merasa puas dan memberikan penilaian yang baik terhadap Empati perawat di Puskesmas Wotu. 
Empati perawat yang ada di ruang rawat inap merupakan hal yang penting untuk dipertahankan dan ditingkatkan karena sangat mempengaruhi kepuasan pasien atas layanan keperawatan yang diterima. Pasien yang puas merupakan harapan dari institusi pelayanan kesehatan karena apabila pasien puas maka memungkinkan pasien untuk berkunjung kembali dan menggunanakan kembali jasa pelayanan yang pernah diterima, sebaliknya jika pasien tidak puas maka akan memiliki persepsi buruk dan menceritakan kepada orang lain pengalaman buruknya sehingga hal tersebut berdampak negatif pada intitusi layanan kesehatan tersebut dan memungkinkan untuk tidak menggunakan kembali jasa layanan yang pernah diterima.

Peneliti berasumsi bahwa semakin tingi empati perawat dalam pelayanan keperawatan yang diberikan maka semakin tinggi juga kepuasan pasien yang dirasakan oleh pasien di ruang rawat inap Puskesmas Wotu. Hal ini sejalan dengan pendapat Muninjaya (2015) yang menyatakan kepuasan pelanggan dapat dilihat dari tinggi rendahnya mutu pelayanan yaitu persepsi pelanggan terhadap kesesuaian tingkat harapan pelanggan sebelum mereka menerima jasa pelayanan dengan sesudah menerima pelayanan yang mereka terima. Penelitian ini juga sejalan dengan penelitian Walansendow, dkk (2017) yang menemukan bahwa adanya hubungan antara empati perawat dengan tingkat kepuasan pasien di RSUD Sinjai.

\section{Hubungan Aspek Sifat mendukung Perawat dengan Kepuasan Pasien Rawat} Inap di Puskesmas Wotu

Dukungan (supportiveness) adalah situasi yang terbuka untuk mendukung komunikasi berlangsung efektif. Hubungan interpersonal yang efektif adalah hubungan di mana terdapat sifat mendukung. Individu memperlihatkan sifat mendukung dengan bersikap deskriptif bukan evaluatif, spontan bukan strategik.

Komunikasi yang efektif apabila adanya sikap saling mendukung antara satu sama lain. Artinya masing-masing dari dari pihak yang melakukan komunikasi memiliki komitmen untuk saling mendukung terselenggaranya komunikasi secara terbuka. Dukungan merupakan pemberian dorongan atau pengobaran semangat kepada orang lain dalam suasana hubungan komunikasi. Sehingga dengan adanya dukungan dalam situasi apapun, komunikasi interpersonal akan bertahan lama karena tercipta suasana yang mendukung.

Berdasarkan hasil penelitian diketahui bahwa mayoritas sifat mendukung perawat dalam menangani 
pasien dalam kategori baik. Hal ini terlihat dari hasil jawaban kuasioner sifat mendukung perawat yang sebagian besar menjawab dengan baik. Akan tetapi, ada juga beberapa pasien yang memberikan penilaian yang kurang baik.

Perawat di Puskesmas Wotu Perawat memperlakukan pasien dengan hormat sewaktu berkomunikasi. Selain itu, Perawat selalu memotivasi pasien sewaktu berkomunikasi tentang pengobatan. Hal ini menunjukkan bahwa respek perawat kepada pasien mendapat sambutan yang begitu baik dari pasien.

Namun yang menjadi kendala dari penanganan di ruangan adalah kesan pertama atau perkenalan pada saat bertemu dengan dokter dan perawat dikarenakan dokter yang terkesan cuek dan ketika berada diruangan juga meskipun ramai pasien tapi suasananya hening sehingga pasien merasa gugup pada awal pemeriksaan. Oleh karena itu sifat mendukung yang ditunjukan perawat itu muncul ketika melakukan komunikasi dan direspon baik oleh pasien itu sendiri dengan memberikan reaksi baik atas apa yang disampaikan oleh perawat. Jika ditinjau dari aspek dukungan perawat maka penelitian ini juga seirama dengan hasil penelitian yang dilakukan oleh Asdawati, S., A, I., Kapalawi, \& Irwandy. (2014)

\section{Hubungan Aspek Sikap Postif Perawat dengan Kepuasan Pasien Rawat Inap di Puskesmas Wotu}

Gambaran dari sikap positif perawat terhadap pasien rawat inap di Puskesmas Wotu menunjukkan nilai yang cukup baik. Menurut Purwanto dan Sulistyastuti (2008), sikap merupakan suatu perbuatan atau tingkah laku sebagai reaksi (respons) terhadap sesuatu rangsangan atau stimulus, yang disertai dengan pendirian dan perasaan orang itu.

Menurut peneliti sesuai yang ada di lapangan sikap perawat yaitu dengan menghargai pasien dan menunjukan sikap yang baik kepada siapa saja terlebih saat melayani kebutuhan pasien sehingga baik pasien maupun keluarga pasien merasa nyaman, namun ada juga terkadang kurang memperhatikan sikap saat melakukan tindakan keperawatan.

Perawat di Puskesmas Wotu juga menunjukkan sikap positif dalam mendukung pasien yang dia tangani, melalui saran-saran dan pantanganpantangan yang diberitahukan dokter sesuai dengan permasalahan dari masing-masing pasien. Dengan pemberian saran-saran yang tepat kepada pasien dan apa-apa saja yang menjadi pantangan pasien, serta dengan pemberian obat yang tepat maka dokter sudah bersifat mendukung pasiennya. 
Berdasarkan hasil analisis dengan menggunakan uji statistic chi-square menunjukan bahwa hasil analisis terhadap sikap positif perawat dengan kepuasan pasien rawat inap di Puskesmas Wotu, penelitian ini didapatkan sebagian besar sikap positif daripada perawat dibutuhkan agar mempengaruhi kepuasan pasien. Jadi dapat dikatakan bahwa kepuasan pasien sangat di tentukan dari sikap seorang perawat.

Komunikasi terapeutik merupakan komunikasi profesional yang mengarah pada tujuan penyembuhan pasien. Dengan demikian Kepuasan pasien terjadi apabila apa yang menjadi kebutuhan, keinginan, harapan pasien dapat dipenuhi, maka pasien akan puas.

Menurut peneliti sikap merupakan aspek penting yang harus dilakukan oleh perawat dalam praktik keperawatan. Pelayanan keperawatan yang didasari oleh sikap yang diperlihatkan atau dilakukan dengan efektif dapat mendorong kesehatan serta mampu meningkatkan kualitas pelayanan kesehatan. Selain itu, menjadi perawat harus punya sifat positif, dan tidak boleh berburuk sangka kepada orang lain, bagaimana bisa berkomunikasi dengan baik dengan pasien kalau di dalam hati dan pikiran ada perasaan tidak enak pada orang lain.
Hasil penelitian ini masih sejalan dengan yang ditemukan oleh Asdawati, S., A, I., Kapalawi, \& Irwandy. (2014) bahwa sikap positif perawat memiliki hubungan dengan tingkat kepuasan pasien di RSUD Sinjai.

\section{Hubungan Aspek Kesetaraan antara} perawat dan pasien dengan Kepuasan

\section{Pasien Rawat Inap di Puskesmas Wotu}

Komunikasi antarpribadi akan lebih efektif bila suasananya setara. Artinya, ada pengakuan secara diam-diam bahwa kedua belah pihak menghargai, berguna, dan mempunyai sesuatu yang penting untuk disumbangkan. Kesetaraan meminta kita untuk memberikan penghargaan positif tak bersyarat kepada individu lain. Dalam suatu hubungan antarpribadi yang ditandai oleh kesetaraan, ketidaksependapatan dan konflik lebih dilihat sebagai upaya untuk memahami perbedaan yang pasti ada daripada sebagai kesempatan untuk menjatuhkan pihak lain.

Perawat di Puskesmas Wotu bersikap adil ketika melakukan pemeriksaan, maka pasien yang berada di ruangan pemeriksaan tidak tegang karena pasien melihat perawat memberikan pelayanan yang baik dengan pasien-pasien sebelumnya. Perawat dalam melakukan pemeriksaan menjelaskan dengan kata-kata yang mudah dipahami, dengan lebih menyederhanakan bahasanya 
agar dapat di mengerti pasien dari berbagai golongan.

Dengan bersikap setara dengan orang lain maka pelayanan yang dilakukan perawat dapat terlaksana dengan baik karena dengan menunjukkan kesetaraan maka pasien tidak lagi membatasi dirinya dan tidak ragu dalam berkomunikasi dengan perawat, sehingga permasalahan yang dialami pasien dapat menemukan solusi yang tepat dan tidak terjadi salah paham yang tidak perlu diantara keduanya ketika pemeriksaan berlangsung, agar sesuai dengan yang dikatakan Devito (1997) yang menyatakan bahwa dalam suatu hubungan antarpribadi yang ditandai oleh kesetaraan, ketidaksependapatan dan konflik lebih dilihat sebagai upaya untuk memahami perbedaan yang pasti ada daripada sebagai kesempatan untuk menjatuhkan pihak lain.

Penelitian ini sesuai dengan konsep yang dikembangkan oleh Siregar (2016) dan juga sejalan dengan hasil yang ditemukan oleh Asdawati, S., A, I., Kapalawi, \& Irwandy. (2014) bahwa terdapat hubungan antara aspek kesetaraan antara perawat dan pasien dengan kepuasan pasien. Berdasarkan hasil penelitian yang dilakukan di Puskesmas Wotu tentang hubungan komunikasi terapeutik dengan kepuasan pasien ruang rawat inap, diperoleh hasil bahwa aspek keterbukaan (openess), empati (emphaty), sifat mendukung (supportiveness), sikap positif (positiveness) dan kesetaraan (equality) memiliki hubungan dengan kepuasan pasien rawat inap di Puskesmas Wotu. Namun, masalah yang dihadapi oleh Puskesmas Wotu adalah meskipun petugas kesehatan telah berupaya dalam meningkatkan mutu pelayanan kesehatan khususnya dalam hal komunikasi serta kepuasan pasien, tetapi belum ada pedoman internal tentang komunikasi terapeutik yang dibuat agar peningkatan mutu pelayanan berjalan secara sistematis dan berkelanjutan.

Pedoman internal ini juga sangat penting agar diterapkan di semua Puskesmas di Kabupaten Luwu Timur oleh karena berdasar hasil penelitian bahwa terdapat hubungan komunikasi terapeutik dengan kepuasan pasien di Puskesmas, sehingga perlu untuk disusun suatu pedoman mutu internal di Puskesmas Wotu Kabupaten Luwu Timur yang dapat di terapkan di Puskesmas lain se-Kabupaten Luwu Timur.

Pedoman internal ini juga sangat penting agar diterapkan di semua Puskesmas di Kabupaten Luwu Timur oleh karena berdasar hasil penelitian bahwa terdapat hubungan komunikasi terapeutik dengan kepuasan pasien di Puskesmas, sehingga perlu untuk disusun suatu 
pedoman mutu internal di Puskesmas Wotu Kabupaten Luwu Timur yang dapat di terapkan di Puskesmas lain se-Kabupaten Luwu Timur.

\section{KESIMPULAN DAN SARAN}

Penelitian ini menemukan bahwa terdapat hubungan antara komunikasi terapeutik ditinjau dari aspek keterbukaan (openess), empati (emphaty), sifat mendukung (supportiveness), sikap positif (positiveness) dan kesetaraan (equality) antara perawat dan pasien dengan kepuasan pasien ruang rawat inap di Puskesmas Wotu. Saran dari penelitian ini yaitu Puskesmas Wotu dapat meningkatkan kepuasan pasien rawat inapnya melalui peningkatan keterampilan komunikasi terapeutik para perawat yang ada di instalasi rawat inap Puskesmas Wotu.

\section{REFERENSI}

Agus, Erwan Purwanto, and Dyah Ratih Sulistyastuti. 2008. Metode Penelitian Kuantitatif untuk Administrasi Publik dan Masalahmasalah Sosial. Yogyakarta: Penerbit Gaya Media.

Andriani, Aida, and Heru Adita Putra. 2014. "Faktor-Faktor yang Berhubungan dengan Kepuasan Pasien dalam Pelayanan Keperawatan di Ruang Rawat Inap Interna Pria dan Wanita RSUD Dr. Achmad Mochtar Bukittinggi Tahun 2014." Jurnal Ilmu
Kesehatan 'Afiyah (LPPM STIKES

YARSI SUMBAR) 1 (2): 1-7.

Anjaswarni, Tri. 2016. Komunikasi dalam Keperawatan. Jakarta Selatan: Pusat Pendidikan SDM Kesehatan Kementerian Kesehatan Republik Indonesia.

Asdawati, A. Indahwaty Sidin, and Irwandy Kapalawi. 2014. "Gambaran Kepuasan Pasien dalam Pelaksanaan Komunikasi." 819.

Ayuningtyas, Dumilah. 2015. Kebijakan Kesehatan, Prinsip dan Praktik. Jakarta: PT. Raja Grafindo Perkasa.

Barkley, Bruce T., and James H. Saylor. 1994. Customer Driven Project Management - A New Paradigm in Total Quality Implementation. Singapore: McGraw-Hill.

Devito, Joseph A. 2011. Komunikasi Antarmanusia. Tangerang: Karisma Publishing Group.

Ginting, Desmon. 2017. Komunikasi Cerdas - Panduan Berkomunikasi di Dunia Kerja. Jakarta: PT. Elex Media Komputindo.

Ketnawati, Iin, Lutfi Nurdian, and Ruhyana. 2017. Hubungan Persepsi Pasien tentang Pelaksanaan Komunikasi Terapeutik Perawat dengan Tingkat Kepuasan Pasien di Bangsal Flamboyan RSUD Muntilan. Yogyakarta: Universitas 'Aisyiyah Yogyakarta - Digital Library Repository, 112.

Muninjaya, A.A. Gde. 2011. Manajemen Mutu Pelayanan Kesehatan. Kediri: EGC.

Murwani, A., and Istichomah. 2009. Komunikasi Terapeutik Panduan Bagi Perawat. Yogyakarta: Fitramaya. 
Nursalam. 2014. Manajemen Keperawatan: Aplikasi dalam Praktik Keperawatan Profesional. Jakarta: Salemba Medika.

Purwanto, Erwan Agus, and Dyah Ratih Sulistyastuti. 2008. Metode Penelitian Kuantitatif untuk Administrasi Publik dan Masalahmasalah Sosial. Yogyakarta: Penerbit Gaya Media.

Siregar, Nina Siti Salmaniah. 2016. "Komunikasi Terapeutik Dokter dan Paramedis terhadap Kepuasan Pasien dalam Pelayanan Kesehatan pada Rumah Sakit Bernuansa Islami di Kota Medan." Repositori UIN Sumatera Utara, 1220.

Siti, Misi, Zulpahiyana, and Sofyan Indrayana. 2016. "Komunikasi Terapeutik Perawat Berhubungan dengan Kepuasan Pasien." Jurnal Ners dan Kebidanan Indonesia (Journal of Nurse and Midwifery Indonesia) (Universitas Alma Ata Yogyakarta) 4 (1): 30-34.

Walansendow, Vanda Lucyana, Odi R. Pinontoaan, and Sefti Rompas. 2017. "Hubungan antara Sikap dan Teknik Komunikasi Terapeutik Perawat dengan Kepuasan Pasien Rawat Inap di Ruang Eunike RSU GMIM Kalooran Amurang." Jurnal Keperawatan (Program Studi Ilmu Keperawatan Fakultas Kedokteran Universitas Sam Ratulangi) 5 (1): 17. 